\title{
Editorial vol 74(1) March 2021
}

B. N. Chakraborty ${ }^{1,2}$

C Indian Phytopathological Society 2021

Dear Readers,

The first issue, Volume 74 of Indian Phytopathology for January-March 2021 is ready. In this issue there are thirty two articles including three review articles, eighteen research articles, ten short communications and one new report.

Omics-technology based knowledge is increasingly contributing to better understanding of biocontrol strategies. In the first review, Dr. Sarethy and Saharan have provided an overview of the evolution on genomics, proteomics and transcriptomics in the biological control of plant pathogens. In the second review article on "Disease sniffing robots to apps fixing plant diseases: applications of artificial intelligence in plant pathology" Dr. K. Prabha has explored the present status of artificial intelligence technologies in plant pathology and emphasized the challenges and the future prospects. In the third review article, Dr. Malkhan Singh Gurjar and his group have illustrated the complex biology of the pathogen, high genetic variability, detection, genomics and pathogenesis-related genes in Tilletia indica, causing karnal bunt disease of wheat.

Association of defense related enzymes in rice plants at elevated temperature challenged with Xanthomonas oryzae pv. oryzae were evaluated. Efficacy of strobilurin, triazole and propylene bis-dithiocarbamate fungicides in jute plants against Macrophomina phaseolina was determined. Population structure of Rhizoctonia solani inciting sheath blight of rice and prediction model for grey leaf spot disease of fodder sorghum have been elucidated. Using ISSR markers genetic diversity of Colletotrichum population causing anthracnose in fruit crops were analysed. Fungus mediated biogenic synthesis of chitosan nanoparticles, their characterization and combined effects with Trichoderma asperellum

B. N. Chakraborty

bncnbu@gmail.com

Indian Phytopathological Society, New Delhi, India

2 Department of Biological Sciences, Aliah University, Kolkata, India against phytopathogenic fungi have been demonstrated. Natural incidence of aspergilli, penicilli, fusaria and their multiple toxins in the seeds of dried red chillies (Capsicum annum) and aflatoxigenic Aspergillus flavus associated with aflatoxin B1 production in maize have been characterized. Screening of phytochemicals from Auricularia delicata and Auricularia mesenterica and their antioxidant properties have been documented. Morphlogical and molecular characterization of Pyricularia oryzae isolates causing wheat blast in Bangladesh has been reported. Primary incitant of rot complex of small cardamom plant has been confirmed by sequential inoculation of pathogens. GLM-PCA, a method has been demonstrated to detect informative environments and phenotypic stable resistant sources of wheat to yellow rust disease. Distribution and association of agroecological factors influencing garlic rust epidemics in Ethiopia has been emphasized. Differential biochemical responses in resistant and susceptible barley cultivars following infection with Ustilago hordei were elucidated. Trichoderma viride and Pseudomonas fluorescens as bioagents and neem based products have been evaluated against Phytophthora infestans causing late blight disease of potato. Immunodiagnostics for apple stem pitting virus and apple mosaic virus infecting apple and reverse transcription recombinase polymerase amplification assay for detection of onion yellow dwarf virus in onion cultivars were developed. Variability in resistance to barley yellow dwarf virus among Hordeum vulgare has been presented.

Management of bacterial leaf blight of clusterbean, Fusarium root rot of coriander, integrated management of sheath blight disease of rice and compatibility of indigenous Trichoderma isolates with pesticides have been documented. Improved methodology for the isolation of false smut pathogen (Ustilaginoidea virens) of rice has been reported. Fusarium oxysorum causing rhizome rot of ginger and Leptoxyphium sp. causing sooty mold of coconut have been identified. Role of abiotic factors on progression of spot blotch disease of wheat has been worked out. Effect of black point on seed germination parameters in wheat cultivars and 
seed transmission of leaf crinkle disease of urdbean (Vigna mungo) have been demonstrated.

New record on premature defoliation in Zinnia sp. and mycoparasitism of Ampelomyces quisqualis against the powdery mildew pathogen (Golovinomyces cichoracearum) has been discussed.

Authors, reviewers, editorial board members, executive council members of Indian Phytopathological Society and business manager who have put in lot of efforts to bring out timely publication of this issue are gratefully acknowledged. Authors are requested to submit the best research/review articles to Indian Phytopathology to maintain its quality and high standards.

Prof. B. N. Chakraborty

Chief Editor, Indian Phytopathology.

Publisher's Note Springer Nature remains neutral with regard to jurisdictional claims in published maps and institutional affiliations. 